Vol. 8(13), pp. 543-549, 3 April, 2014

DOI: $10.5897 / J M P R 2013.5217$

ISSN 1996-0875

Copyright (C) 2014

Journal of Medicinal Plant Research

Author(s) retain the copyright of this article

http://www.academicjournals.org/JMPR

\title{
Effect of adenine sulphate on in vitro mass propagation of Stevia rebaudiana Bertoni
}

\author{
Mohd. Kamran Khan ${ }^{1}$, Pragati Misra ${ }^{1,2 \star}$, Taru Sharma ${ }^{1}$, P. K. Shukla ${ }^{2}$ and P. W. Ramteke ${ }^{2}$ \\ ${ }^{1}$ Department of Molecular and Cellular Engineering, Jacob School of Biotechnology and Bioengineering, India. \\ ${ }^{2}$ Department of Biological Sciences, School of Basic Sciences, Sam Higginbottom Institute of Agriculture, Technology \\ and Sciences, (Formerly AAI-DU, Deemed to be University), Allahabad-211 007, Uttar Pradesh, India.
}

Received 29 August, 2013; Accepted 19 March, 2014

\begin{abstract}
Stevia rebaudiana, a medicinal plant normally used as a natural herbal sweetener, has documented properties of antimicrobial, antihypertensive and anti-hyperglycemic and hence a boon to diabetic people. An efficient protocol has been developed for the in vitro plant regeneration established from nodal explants of stevia. Best shoot proliferation was observed when nodal explants were inoculated on Murashige and Skoog (MS) medium supplemented with Kinetin (9.3 $\mu \mathrm{M})$ and adenine sulphate (Ads) $40 \mathrm{mg} / \mathrm{L}$. Proliferated shoots were transferred to rooting media having different concentration of $\alpha-n-$ Naphthalene acetic (NAA) acid and Indole-3-butyric acid (IBA). Best rooting was observed with NAA 5.3 $\mu \mathrm{M}$. The plantlets were successfully subjected to hardening media containing soil, soilrite and vermiculite $(2: 1: 1 \mathrm{w} / \mathrm{w})$ and then rooted plant transferred to pots and acclimatized, which showed $65 \%$ survival in the field with normal growth.
\end{abstract}

Key words: Stevia rebaudiana, adenine sulphate, in vitro.

\section{INTRODUCTION}

Stevia rebaudiana Bertoni (family: Asteraceae) is a perennial herb and natural sweetener plant commonly known as 'Sweet weed', 'Sweet leaf', 'Sweet herbs' and 'Honey leaf' which is estimated to be 300 times sweeter than cane sugar (Chalapathi and Thimmegowda, 1997; $\mathrm{Liu}$ and $\mathrm{Li}, 1995)$. The leaves of Stevia are the source of diterpene glycosides: stevioside and rebaudioside (Yoshida, 1986). The extracts of $S$. rebaudiana and purified stevioside began to be utilized commercially for sweetening and flavoring foods and beverages in Japan in the mid 1970s, in order to substitute for several synthetic sweeteners. Plant extract of Stevia have important industrial uses in beverages, energizers as well as medicinal uses such as low uric acid treatment, vasodilator cardiotonic, anesthetic and anti-inflammatory. Stevia is also helpful in treatment of hypoglycemia and diabetes because it nourishes pancreas and thereby helps to restore its normal function, and $35.2 \%$ fall in normal blood sugar levels 6 to $8 \mathrm{~h}$ following the ingestion of Stevia leaf extract (Soejarto et al., 1983; Oviedo, 1971).

Due to difficulties of growing Stevia, tissue culture could be the only alternative for rapid mass propagation of Stevia plants because seed of Stevia show very low germination percentage and propagation by seeds does not allow the production of homogeneous population resulting in great variation in important feature like sweetening level and composition; vegetative propagation

${ }^{*}$ Corresponding author. E-mail: pragatimisra3@rediffmail.com. Tel: +919452517350.

Author(s) agree that this article remain permanently open access under the terms of the Creative Commons Attribution License 4.0 International License 
is also limited by the low number of individuals obtained from single plant (Miyazaki and Watanabe, 1974; Nakamura and Tamura, 1985; Goettemoeller and Ching, 1999; Ferreira and Handro, 1988). Adenine sulphate acts as a precursor for natural cytokinin synthesis or enhances natural cytokinin biosynthesis; the compounds produced could be more effective in causing the physiological response than the cytokinins added to the Murashig and Skoog (MS) culture medium. The benefits of adenine are often only noticed when it is associated together with cytokinins such as benzylaminopurine (BAP) or kinetin (Van Staden et al., 2008). Our results suggest that kinetin, in combination with Ads, improves the process of organogenesis. The purpose of the present study was to optimize an in vitro plant regeneration system on the basis of the effect of adenine sulphate with different growth regulators: kinetin, BAP and $\alpha$-n-Naphthalene acetic (NAA) for the mass propagation of Stevia which has high demand in the pharmaceutical industry and Indian System of Medicine.

\section{MATERIALS AND METHODS}

\section{Plant}

The twigs (about 5 to $6 \mathrm{~cm}$ ) of pot grown $S$. rebaudiana plants were collected from the polyhouse at Sam Higginbottom Institute of Agriculture, Technology and Sciences (SHIATS), Allahabad.

\section{Explant sterilization}

The twigs with node explants were washed in running tap water and then washed again thoroughly by adding a few drops of Tween-20 to remove the superficial dust particles as well as fungal and bacterial spores. Explants were sterilized with $0.1 \%$ mercuric chloride for $4 \mathrm{~min}$ followed by rinsing for five times with sterile double distilled water.

\section{In vitro culture condition and germination}

Sterilized nodal segments (with a single axillary bud) about 0.8 to $1.0 \mathrm{~cm}$ were prepared aseptically and were implanted vertically on MS medium (Murashige and Skoog, 1962) fortified with specific concentrations of growth regulators 6-benzylaminopurine (BAP), kinetin and NAA singly or along with Ads as additive. The medium was gelled with $8 \mathrm{~g} / \mathrm{L}$ agar and supplemented with $30 \mathrm{~g} / \mathrm{L}$ sucrose. The $\mathrm{pH}$ was adjusted with $1 \mathrm{~N} \mathrm{NaOH}$ and $1 \mathrm{~N} \mathrm{HCl}$ at 5.8 before autoclaving. The cultures were incubated at $25 \pm 2^{\circ} \mathrm{C}$ under $16 \mathrm{~h}$ light and $8 \mathrm{~h}$ dark photoperiod provided by cool white fluorescent tubes with 3000 lux intensity and relative humidity 72 to $75 \%$. Subcultures were done every 15 days interval. Nodal segments from the proliferated shoots were subcultured again after 20 days for further multiple shoot induction. Regenerated multiple shoots were cut and individual shoots were placed on MS medium containing different concentrations of IBA and NAA for root induction. After development of sufficient roots, the plantlets were gradually pulled out from the medium and were subjected to hardening using foam cups with polythene cover. Medium for hardening methods was different combinations of soil, soilrite and vermiculite supplemented with half strength MS liquid medium (without organics) twice a week, cultures were kept under the same controlled photoperiod and temperature. Hardened plantlets were

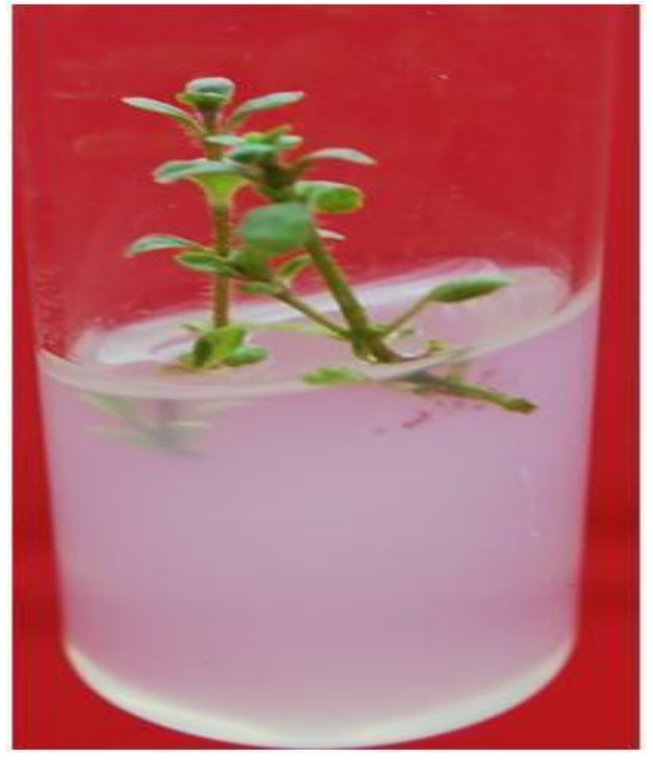

Figure 1. Shoot initiation from nodal explant of S. rebaudiana after 2 weeks.

allowed to be transferred in a polyhouse for 30 days, then hardening plants were transferred to the field and plants were survived with normal growth and morphology.

\section{Statistical analysis}

The statistical analysis was performed using one-way analysis of variance (ANOVA) and the significance of differences among treatment means were contrasted with Tukey's Honestly Significant Difference Test (HSD) at $\mathrm{P}<0.05$.

\section{RESULTS}

Nodal explant showed emergence of shoot buds within 7 days after inoculation on MS media supplemented with MS, kinetin $(9.3 \mu \mathrm{M})$, NAA $(0.5 \mathrm{mg} / \mathrm{L})$ and Ads $(40 \mathrm{mg} / \mathrm{L})$ (Figure 1). In the present investigation, Ads showed a marked improvement in shoot multiplication rate and emergence of shoot bud of $S$. rebaudiana. Proliferated nodal explants were subcultured for 25 to 30 days on MS media. To examine the effect of adenine sulphate on shoots proliferation the MS media was supplemented with or without kinetin. Profuse multiplication of shoot after 50 to 55 days, with maximum numbers of shoots $(65$ shoots/explant) with increased shoot length were produced on MS media supplemented with kinetin (9.3 $\mu \mathrm{M})$ and Ads (40 mg//L) (Figure 2) whereas, MS media containing kinetin $(9.3 \mu \mathrm{M})$ and Ads $(10 \mathrm{mg} / \mathrm{L})$ produced the minimum number of shoots (10 shoots/explant) (Table 2 and Figure 3). MS media containing kinetin alone $(9.3 \mu \mathrm{M})$ produced 25 shoots per explant (Table 1$)$. Adenine sulphate was also added along with kinetin and NAA, the best response (30 shoots/explant) was observed on MS, kinetin $(9.3 \mu \mathrm{M})$, NAA $(5.3 \mu \mathrm{M})$ and adenine 
Table 1. Effect of different concentrations of kinetin on shoot multiplication of $s$. rebaudiana.

\begin{tabular}{ccc}
\hline Kinetin (mg/L) & Average no. of shoots & Average length of shoots (inches) \\
\hline 0.5 & 4 & 2.2 \\
1.0 & 6 & 2.4 \\
1.5 & 14 & 2.9 \\
2.0 & 25 & 4.8 \\
2.5 & 18 & 3.7 \\
3.0 & 8 & 3.1 \\
F-test & $\mathrm{S}$ & $\mathrm{S}$ \\
SD $( \pm)$ & 1.139 & 0.177 \\
CD at $5 \%$ & 2.425 & 0.378 \\
\hline
\end{tabular}

Data represent average number of shoots per explant and average length of shoots in three experiments with three replicates in each.

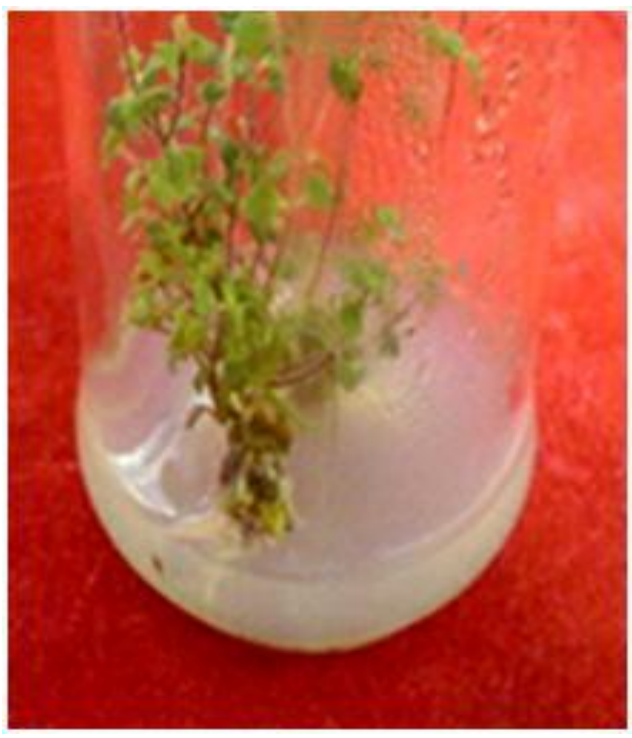

Figure 2. Multiple shoot proliferation in $S$. rebaudiana when cultured on MS with $9.3 \mu \mathrm{M}$ and adenine sulphate $40 \mathrm{mg} / \mathrm{L}$.

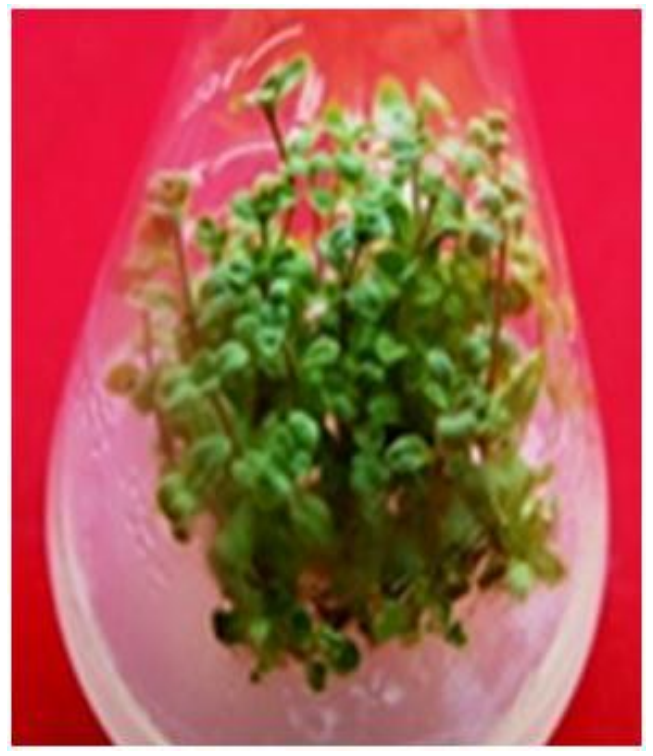

Figure 3. Minimum number of shoot regeneration. sulphate (40 mg/L) (Table 3).

When adenine sulphate was added along with kinetin and BAP, the best response (8 shoots/explant) was observed on MS, kinetin $(9.3 \mu \mathrm{M})$, BAP $(22.2 \mu \mathrm{M})$ and adenine sulphate $(40 \mathrm{mg} / \mathrm{L})$ (Table 4$)$. For rooting of 25 to 30 days old, proliferated shoots were transferred to rooting media having different concentration of NAA (5.3, 8.1 and $10.7 \mu \mathrm{M})$ and IBA $(4.9,9.8$ and $14.7 \mu \mathrm{M})$. The best rooting with the maximum lengths of roots was observed with NAA $5.3 \mu \mathrm{M}$ (Table 5 and Figure 4). The 60 to 65 days old plantlets were successfully subjected to hardening media containing soil, soilrite and vermiculite $(2: 1: 1 \mathrm{w} / \mathrm{w})$ showed the maximum survival percentage in the foam cups for 10 to 15 days (Table 6 and Figure 5) and then transferred to pots and grown at 25 to $30^{\circ} \mathrm{C}$ and 75 to $80 \%$ relative humidity. About 70 to $75 \%$ of plantlets were survived in the hardening procedure. These plants were then transferred to the field and after 30 days, $65 \%$ plants were survived with normal growth and morphology.

\section{DISCUSSION}

In the present study, nodal explant from Stevia plants were inoculated on MS media supplemented with different concentrations of kinetin, NAA and Ads for shoot bud initiation. The early study reported that kinetin in combination with Ads are known to improve organogenesis (Gatica et al., 2010). Nodal explant of Stevia placed on MS medium containing $1.0 \mathrm{mg} / \mathrm{L}$ BAP or IBA $0.05 \mathrm{mg} / \mathrm{L}$ for shoot bud initiation (Laribi et al., 2012). The natural and synthetic purine cytokinins are degraded to adenine sulphate and related nucleotides; therefore, the addition of Ads to the medium may retard the degradation 
Table 2. Combined effect of different concentration of adenine sulphate with Kinetin on shoot multiplication of $s$. rebaudiana.

\begin{tabular}{cccc}
\hline Kinetin (mg/L) & $\begin{array}{c}\text { Adenine } \\
\text { sulphate }(\mathbf{m g} / \mathbf{L})\end{array}$ & $\begin{array}{c}\text { Average No. of } \\
\text { shoots }\end{array}$ & $\begin{array}{c}\text { Average length of } \\
\text { shoots (inches) }\end{array}$ \\
\hline 2.0 & 10 & 30 & 4.5 \\
2.0 & 20 & 34 & 4.5 \\
2.0 & 30 & 40 & 5.0 \\
2.0 & 40 & 62 & 8.0 \\
2.0 & 50 & 51 & 6.5 \\
2.0 & 60 & 35 & 5.0 \\
F-test & - & $\mathrm{S}$ & $\mathrm{S}$ \\
SD $( \pm)$ & - & 1.401 & 0.194 \\
CD at $5 \%$ & - & 2.984 & 0.414 \\
\hline
\end{tabular}

Data represent average number of shoots per explant and average length of shoots in three experiments with three replicates in each.

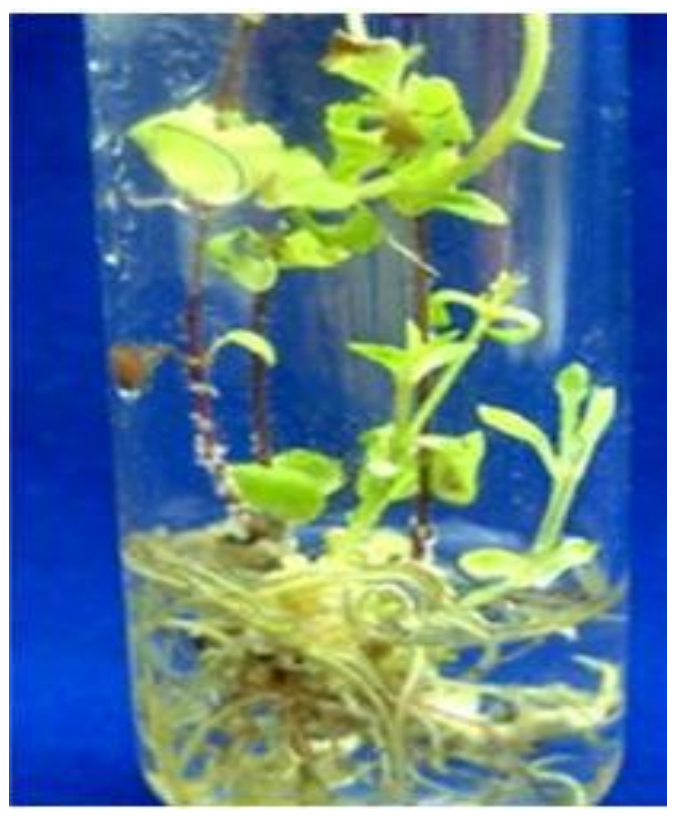

Figure 4. Root induction from isolated shoot.

of cytokinins by feed-back inhibition or by competing for the enzyme systems involved in cytokinin metabolism (Van Staden et al., 2008). Data presented in Table 2 and Figure 2 indicates that, the concentrations of Ads 40 $\mathrm{mg} / \mathrm{L}$ improve the multiplication rate (number of shoot/explant) and length of the shoot when added in combination with kinetin. However, MS media containing kinetin alone did not improve the multiplication rate (Table 1). Adenine sulphate, adenosine and adelynic acid show cytokinin activity and therefore are applied to different culture medium in order to improve growth or to reinforce the response normally attributed to cytokinin action (Gatica et al., 2010).

Adenine sulphate also stimulates somatic embryogenesis and caulogenesis, induces the proliferation of axillary shoots in shoot cultures and promotes adventitious shoot formation indirectly from calli or directly from explants and the benefits of Ads are often only noticed when it is associated together with ammonium nitrate or with cytokinins such as BAP or kinetin (Van Staden et al., 2008). Shoot multiplication also observed MS media supplemented with kinetin, NAA and Ads whereas kinetin, BAP and Ads resulted in lower number of shoots per explant (Tables 3 and 4), respectively). BAP and Indole-3-acetic acid (IAA) combination was superior for induction of shoot bud multiplication from nodal explant of Stevia (Thyagarajan and Venkatachalam, 2012). The combination of $13.3 \mu \mathrm{M}$ BA, $61.8 \mu \mathrm{M}$ Ads and 8.0 $\mu \mathrm{M}$ NAA in MS basal medium showed enhanced shoot multiplication (Dubey et al., 2006). Shoot tips showed better response for shoot proliferation than nodal segments of $S$. rebaudiana as explants.

MS media in half and full strength were equally effective in shoot proliferation. BA $(1.0 \mathrm{mg} / \mathrm{L})$ was superior to all other hormonal treatments for shoot proliferation (Hossain et al., 2008). The medium was supplemented with $1.0 \mathrm{mg} / \mathrm{L} \mathrm{NAA}$ and $4.0 \mathrm{mg} / \mathrm{L}$ BA recommended for $S$. rebaudiana plant regeneration (Suarez and Salgado, 2008). As shown in Table 5 and Figure 4, root induction from proliferated shoot were transferred onto MS media supplemented with different concentration of NAA and IBA. Similarly, the proliferated shoots were individually separated and transferred to rooting media consisting of MS basal medium supplemented with different concentrations of NAA (Sharma et al., 2012). Rooting of the in vitro derived shoots of Stevia could be achieved following subculture in auxin containing medium and root also optimized on MS medium with IBA $2 \mathrm{mg} / \mathrm{L}$ (Sivaram and Mukundan, 2003; Taware et al., 2010). The well rooted plants were transferred into foam cups containing different combination of soil, soilrite and vermiculite (Table 6 and Figure 5). The rooted plantlets of Stevia were hardened in 2:1:1 ratio of sand: soil: vermicomposite 


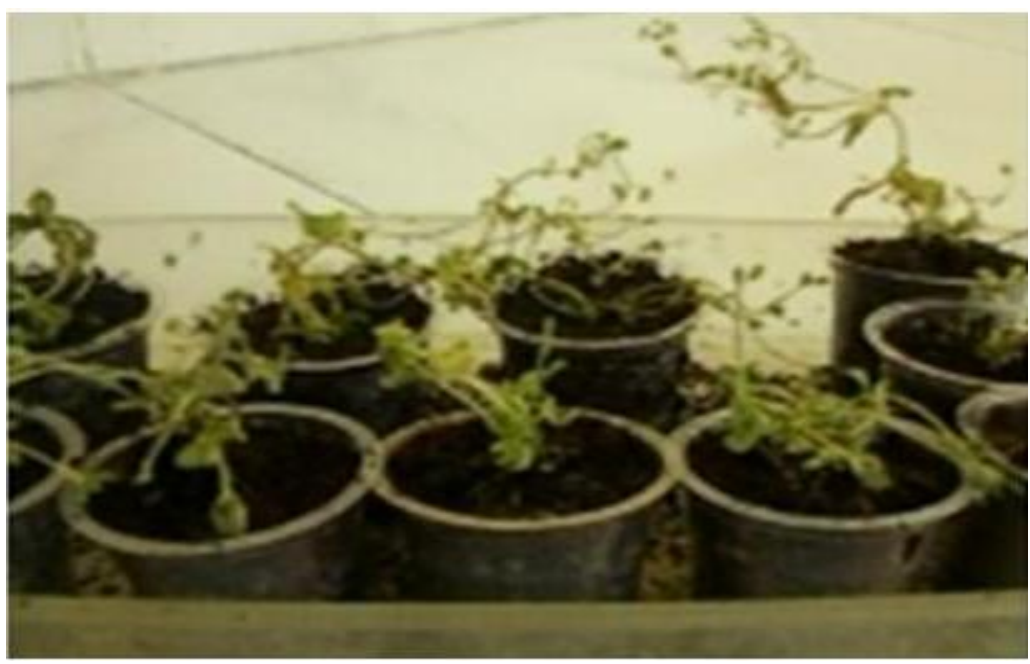

Figure 5. Hardening media containing soil, soilrite and vermiculite (2:1:1 $\mathrm{w} / \mathrm{w})$.

Table 3. Combined effect of different concentration of adenine sulphate with Kinetin and NAA on shoot multiplication of $S$. rebaudiana.

\begin{tabular}{ccccc}
\hline $\begin{array}{c}\text { Kinetin } \\
(\mathbf{m g} / \mathbf{L})\end{array}$ & $\begin{array}{c}\text { NAA } \\
(\mathbf{m g} / \mathbf{L})\end{array}$ & $\begin{array}{c}\text { Adenine sulphate } \\
(\mathbf{m g} / \mathbf{L})\end{array}$ & $\begin{array}{c}\text { Average No. of } \\
\text { shoots }\end{array}$ & $\begin{array}{c}\text { Average length of } \\
\text { shoots (inch) }\end{array}$ \\
\hline 2.0 & 1.0 & 40 & 30 & 5.0 \\
2.0 & 1.5 & 40 & 24 & 4.8 \\
2.0 & 2.0 & 40 & 19 & 4.5 \\
2.0 & 2.5 & 40 & 16 & 4.5 \\
2.0 & 3.0 & 40 & 11 & 3.0 \\
2.0 & 3.5 & 40 & 9 & 2.4 \\
& F-test & - & $\mathrm{S}$ & $\mathrm{S}$ \\
\multicolumn{2}{c}{ SD $( \pm)$} & - & 0.981 & 0.152 \\
CD at 5\% & - & 2.090 & 0.323 \\
\hline
\end{tabular}

Data represent average number of shoots per explant and average length of shoots in three experiments with three replicates in each.

Table 4. Combined effect of different concentration of adenine sulphate with Kinetin and BAP on shoot multiplication of $s$. rebaudiana.

\begin{tabular}{ccccc}
\hline $\begin{array}{c}\text { Kinetine } \\
(\mathbf{m g} / \mathbf{L})\end{array}$ & $\begin{array}{c}\text { BAP } \\
(\mathbf{m g} / \mathbf{L})\end{array}$ & $\begin{array}{c}\text { Adenine } \\
\text { sulphate }(\mathbf{m g} / \mathbf{L})\end{array}$ & $\begin{array}{c}\text { Average No. of } \\
\text { shoots }\end{array}$ & $\begin{array}{c}\text { Average length of } \\
\text { shoots (inches) }\end{array}$ \\
\hline 2.0 & 1.0 & 40 & 3 & 1.5 \\
2.0 & 2.0 & 40 & 4 & 2.0 \\
2.0 & 3.0 & 40 & 6 & 2.5 \\
2.0 & 4.0 & 40 & 6 & 2.0 \\
2.0 & 5.0 & 40 & 8 & 3.5 \\
2.0 & 6.0 & 40 & 8 & 2.9 \\
F-test & & & $\mathrm{S}$ & $\mathrm{S}$ \\
SD $( \pm)$ & & & 0.882 & 0.125 \\
CD at 5\% & & & 1.878 & 0.266 \\
\hline
\end{tabular}

Data represent average number of shoots per explant and average length of shoots in three experiments with three replicates in each. 
Table 5. Effect of different concentration of NAA and IBA on rooting of S. rebaudiana.

\begin{tabular}{cccccc}
\hline \multicolumn{2}{c}{ Growth regulators (mg/L) } & \multicolumn{3}{c}{ Growth response } \\
\hline S. No & NAA & IBA & $\begin{array}{c}\text { Percent } \\
\text { rooting }\end{array}$ & $\begin{array}{c}\text { Average No. } \\
\text { of roots }\end{array}$ & $\begin{array}{c}\text { Mean length of } \\
\text { roots (cm) }\end{array}$ \\
\hline 1 & 1.0 & 1.0 & 40 & 5 & 2 \\
2 & 1.5 & 2.0 & 45 & 8 & 3 \\
3 & 2.0 & 3.0 & 60 & 10 & 5 \\
4 & 1.0 & - & 80 & 15 & 7 \\
5 & 1.5 & - & 65 & 12 & 5 \\
6 & 2.0 & - & 55 & 8 & 3 \\
F-test & - & - & $\mathrm{S}$ & - & - \\
SD $( \pm)$ & - & - & 1.674 & - & - \\
CD at 5\% & - & - & 3.349 & - & - \\
\hline
\end{tabular}

Data represent percent rooting, average number of roots per shoots and mean length of roots in three experiments with three replicates in each.

Table 6. Survival percentage of micro shoots using different substrates for hardening.

\begin{tabular}{clc}
\hline S. No & Soil composition for hardening $(\mathbf{w} / \mathbf{w})$ & Percentage of survival \\
\hline 1 & Soil + Soilrite $(1: 1)$ & 10 \\
2 & Soil + Soilrite $(2: 1)$ & 30 \\
3 & Soil + Vermiculite $(1: 1)$ & 45 \\
4 & Soil + Soilrite + Vermiculite $(2: 1: 1)$ & 75 \\
5 & Soil + Soilrite + Vermiculite $(2: 2: 1)$ & 50 \\
6 & Soil + Soilrite + Vermiculite $(2: 2: 2)$ & 30 \\
7 & Soil + Soilrite + Vermiculite $(1: 2: 2)$ & 10 \\
F-test & & $\mathrm{S}$ \\
SD $( \pm)$ & & 1.401 \\
CD at 5\% & & 2.984 \\
\hline
\end{tabular}

Data represent average percentage of survival of three experiments with three replicates in each.

were successfully established in soil (Sairkar et al., 2009). Hardened plants showed vigorous and uniform growth in the field similar to mother plants.

\section{Conclusion}

The present study demonstrates a simple and efficient method for high frequency direct shoot regeneration from nodal explants of $S$. rebaudiana. The system is rapid and maximum of shoots (65 shoots/explant) with increased shoot length were produced on MS media supplemented with kinetin $(9.3 \mu \mathrm{M})$ and Ads $(40 \mathrm{mg} / \mathrm{L})$. Proliferating shoot cultures were established by repeatedly subculturing the nodes on the same medium. Maximum rooting occurred in shoots cultured on half strength MS medium supplemented with $5.3 \mu \mathrm{M}$ NAA.

\section{Conflict of Interests}

The author(s) have not declared any conflict of interests.

\section{ACKNOWLEDGEMENT}

Authors are grateful to Vice-Chancellor and Dean, College of Biotechnology and Bioengineering, SHIATS, Allahabad for providing necessary facilities.

\section{REFERENCES}

Chalapathi T, Thimmegowda S (1997). Natural Noncalorie Sweetener (Stevia rebaudiana Bertoni) A future crop of India. Crop Res. 14:347350.

Dubey H, Kumar M, Haider ZA (2006). In vitro morphogenesis of Stevia: the naturally occurring sweet plant-a fast and efficient method to propagate Stevia by tissue culture. J. Res. 18:1-9.

Ferreira CM, Handro W (1988). Production, Maintenance and plant regeneration from cell suspesion cultures of Stevia rebaudiana (Bert), Plant Cell Rep. 7:123-126.

Gatica AAM, Muñoz VJ, Ramírez FP, Valdez MM (2010). In vitro plant regeneration system for common bean (Phaseolus vulgaris): effect of $\mathrm{N}^{6}$-benzylaminopurine and adenine sulphate. Electronic J. Biotechnol. 13(1):0717-3458.

Goettemoeller J, Ching A (1999). Seed germination in Stevia rebaudiana. In Janick J (eds) Perspectives on new crops and new uses. ASHS press, Alexandria, pp. 510-511. 
Hossain MA, Shamim Kabir AHM, Jahan TA, Hasan MN (2008). Micropropagation of Stevia. Int. J. Sustain. Crop Prod. 3:1-9.

Laribi B, Rouatbin N, Kouki K, Bettaieb T (2012). In vitro Propagation of Stevia rebaudiana (Bert.)-A non-caloric sweetener and antidiabetic medicinal plant. Int. J. Med. Arom. Plants 2(2):333-339.

Liu J, Li SFY (1995). Separation and determination of stevia sweeteners by capillary electrophoresis and high performance liquid chromatography. J. Liq. Chrom. 18:1703-1719.

Miyazaki Y, Watanabe H (1974). Studies on the cultivation of Stevia rebaudiana Bertoni; on the propagation of the plant (Eng. abstr.). Jpn. J. Trop. Agric. 17:154-157.

Murashige T, Skoog FA (1962). Revised medium for rapid growth and bioassays with tobacco tissue cultures. Physiol. Plant 15:473-497.

Nakamura S, Tamura Y (1985). Variation in the main glycosides of Stevia (Stevia rebaudiana Bertoni). Jpn. J. Trop. Agric. 29:109-116.

Oviedo CA (1971). Accion hipoglicemiante de la Stevia rebaudiana Bertoni (Kaa-he-e). Excerpta Med. 208:92-93.

Sairkar P, Chandravanshi MK, Shukla NP, Mehrotra NN (2009). Mass production of an economically important medicinal plant Stevia rebaudiana using in vitro propagation techniques. J. Med. Plants Res. 3:266-270.

Sharma T, Khan MK, Misra P, Shukla PK (2012). Micropropagation of Kinnow through nodal explants. Bioscan 7:295-297.

Sivaram L, Mukundan U (2003). In vitro culture studies on Stevia rebaudiana. In vitro Cell Dev. Biol. Plant 39:520-523.

Soejarto DD, Compadre CM, Medon PJ, Kamath SK, Kinghorn AD (1983). Potential Sweetening Agents of Plant Origin, II. Field Search for Sweet-Tasting Stevia Species. Econ. Bot. 37:71-79.

Suarez IE, Salgado JA (2008). In vitro propagation of Stevia rebaudiana Bert. (Asteraceae Eu-patorieae) via organogénesis. Enero Junio 13:40-48.
Taware AS, Mukandam DS, Chavan AM, Taware SD (2010). Comparative studies of in vitro and in vivo grown plants and callus of Stevia rebaudiana (Bertoni). Int. J. Integr. Biol. 9:10-15.

Thyagarajan M, Venkatachalam $P$ (2012). Large scale in vitro propagation of Stevia rebaudiana (bert) for commercial application: Pharmaceutically important and antidiabetic medicinal herb. Ind. Crop Prod. 37:111-117.

Van Staden J, Zazimalova E, George EF (2008). Plant growth regulators II, Plant Propagation by Tissue Culture: Cytokinins, their analogues and antagonist. In George E F, Hall M, De Kleck GJ (eds) Academic press, Netherland, pp. 205-226.

Yoshida S (1986). Studies on the production of sweet substances in Stevia rebaudiana: I. determination of sweet glucosides in Stevia plant by thin layer chromato-scanner and their accumulation patterns with plant growth. Jpn. J. Crop Sci. 55:189-195. 